\title{
Colonization of methicillin-resistant Staphylococcus aureus among healthcare students: an integrative review
}

\author{
Erika Morganna Neves de Oliveira', Ana Raquel Batista de Carvalho", Adriano Menis Ferreira"', Luana Kelle Batista Mourav", \\ Andreia Rodrigues Moura da Costa Vallev, Daniela Reis Joaquim de Freitas" ${ }^{\mathrm{V}}$, Maria Eliete Batista Moura ${ }^{\mathrm{VII}}$ \\ Nursing Postgraduate Program, Universidade Federal do Piauí (UFPI), Teresina (Pl), Brazil; Nursing Postgraduate Program, \\ Universidade Federal de Mato Grosso do Sul, Três Lagoas (MG), Brazil; and Department of Dentistry, Centro Universitário \\ Santo Agostinho, Teresina (PI), Brazil
}

'MSc, PhD. Nurse, Nursing Postgraduate Program, Universidade Federal do Piauí (UFPI), Teresina (PI), Brazil.

(D) https://orcid.org/0000-0001-8588-6290

"MSc. Doctoral Student, Nursing Postgraduate Program, Universidade Federal do Piauí (UFPI), Teresina (PI), Brazil.

(D) https://doi.org/0000-0001-5287-1084

I"PhD. Nurse and Professor, Nursing

Postgraduate Program, Universidade Federal de Mato Grosso do Sul (UFMS), Três Lagoas (MS), Brazil.

(ID) https://orcid.org/0000-0002-4054-768X

"vphD. Dentist and Professor, Department of Dentistry, Centro Universitário Santo Agostinho, Teresina (PI), Brazil.

(DD https://orcid.org/0000-0003-4917-7598

vPhD. Nurse and Professor, Nursing Postgraduate Program, Universidade Federal do Piauí (UFPI),

Teresina (PI), Brazil.

(D) https://orcid.org/0000-0002-2706-0711

vPhD. Biologist and Professor, Department of Microbiology, Universidade Federal do Piauí (UFPI), Teresina (PI), Brazil.

(ID https://orcid.org/0000-0002-5632-0332

VIPhD. Nurse and Professor, Nursing

Postgraduate Program, Universidade Federal do Piauí (UFPI), Teresina (PI), Brazil.

(D) https://orcid.org/0000-0001-9988-1992

KEY WORDS (MeSH terms):

Students, health occupations.

Methicillin resistance.

Methicillin-resistant Staphylococcus aureus.

Staphylococcus aureus

Students.

AUTHORS' KEYWORDS:

Multiresistance.

Healthcare students.

Colonization

Microorganisms

\begin{abstract}
BACKGROUND: Methicillin-resistant Staphylococcus aureus (MRSA) infection is a worldwide concern given its presence even in non-hospitalized healthy individuals, such as university students.

OBJECTIVE: To identify in the literature the prevalence of colonization by MRSA among healthcare students.

DESIGN AND SETTING: Integrative review of the literature conducted in Universidade Federal do Piauí. METHOD: A search for primary studies was performed in the following databases: Medical Literature Analysis and Retrieval System on-line; Cumulative Index to Nursing and Allied Health Literature; Web of Science; Scopus; and LILACS.

RESULTS: This review included 27 studies that demonstrated MRSA infection prevalence ranging from 0.0 to $15.3 \%$ among students.

CONCLUSION: The prevalence of colonization of MRSA among healthcare students is high, and the nasal cavity was cited as an important reservoir location for these microorganisms.
\end{abstract}

\section{INTRODUCTION}

Staphylococcus aureus is considered to be a persistent member of the human endogenous microbiota and has historically been associated with important and serious cases of infection. It has the ability to rapidly develop resistance to antibiotics. Methicillin-resistant Staphylococcus aureus (MRSA) is considered to be a paradigm for bacterial infections, since it is associated with high rates of morbidity and mortality. ${ }^{1-3}$

In assisting carriers of bacterial infections or colonized or infected patients, or in handling contaminated objects, healthcare workers' hands can become contaminated. These workers may subsequently transmit the microorganism to other patients. However, this situation is not exclusive to the hospital environment. Clinically manifested diseases in the community or in professionals and/or patients may lead to situations in which some individuals are asymptomatic carriers, also called colonized individuals or simply carriers, when the disease is present in the host organism without causing apparent manifestations. ${ }^{1,4}$ In the United States and Taiwan, the prevalence of strains acquired in the community is $52 \%$, thus exceeding the proportion of strains acquired in hospital environments. ${ }^{5}$ There have also been reports of cases of MRSA acquired in the community. ${ }^{6,7}$

Healthcare students play an important role in the epidemiology and pathogenesis of Staphylococcus aureus infection and can act as a source of dissemination both in the community and in hospital environments, and for carrying bacteria from one of these environments to another. ${ }^{1}$

In Brazil, this topic has been little addressed, but it is known that the presence of MRSA among students has been gradually spreading. ${ }^{1}$ Hence, it has become relevant to summarize the knowledge of MRSA that has resulted from research on this subject.

\section{OBJECTIVE}

The objective of this study was to identify in the literature the prevalence of colonization by methicillin-resistant Staphylococcus aureus among healthcare students. 


\section{METHODS}

\section{Research design}

This study was an integrative review of the literature, incorporating a method of searching for secondary data. ${ }^{8}$ To preserve methodological rigor, the following steps were taken to conduct this review: formulation of the research question; idealization of sampling plan and data collection strategies; extraction of relevant data from studies included in the review; and, finally, analysis and interpretation of the data. ${ }^{8}$

The research question was elaborated in accordance with the PVO strategy ( $\mathrm{P}$ - population; $\mathrm{V}$ - variable of interest; $\mathrm{O}$ - outcome). Thus, in line with the objective of the study, the following structure was used: P - healthcare students; V - methicillin-resistant Staphylococcus; O - prevalence. ${ }^{9}$ Therefore, the following question was asked: "What evidence is available in the literature regarding the prevalence of methicillin-resistant Staphylococcus aureus colonization among healthcare students?"

\section{Data collection period}

Searching for and selection of studies took place between the months of November 2019 and January 2020 and were carried out by two independent reviewers. Any divergences were resolved by a third reviewer.

\section{Selection criteria}

After the search stage, original articles were selected, based on reviewing their titles and abstracts, in accordance with the following inclusion criteria: original articles covering the population of undergraduate students in the field of healthcare who experienced clinical activities that brought them into direct contact with patients.

The full text of each article was then read, with a view to choosing studies that answered the research question. Through this process, articles involving high school or technical students, those that did not comply with selection criteria mentioned above, those that did not answer the research question and those that were duplicates were excluded, as also were opinion articles, theoretical reflections, dissertations and book chapters.

\section{Data collection}

The following databases were selected: Medical Literature Analysis and Retrieval System online (MEDLINE) via National Library of Medicine National Institutes of Health (PubMed); Cumulative Index to Nursing and Allied Health Literature (CINAHL); Web of Science; Scopus; and Literatura Latinoamericana e do Caribe em Ciências da Saúde (LILACS) via Biblioteca Virtual em Saúde (BVS).

The descriptors and keywords used in the search were applied in accordance with particularities of each database. They were obtained by consulting the Descritores em Ciências da Saúde (DeCS), Medical Subject Headings $(\mathrm{MeSH})$ and titles from CINAHL. During the search, descriptors were cross-referenced with each other using the Boolean operators "or" and "and". Descriptors were inserted in the English language, since all journals indexed in these databases have descriptors in English in their articles; with the exception of BVS, in which descriptors were inserted in English and Portuguese. To expand the search, there was no limitation on the time of publication or language. Table 1 shows the descriptors used in this study and summarizes how the search was carried out.

Table 1. Descriptors used in the search strategy for primary articles. Teresina (PI), Brazil, 2020

Descriptors and Keywords
BVS
Estudantes OR Estudantes de Ciências da Saúde OR Estudantes de Enfermagem OR Estudantes de Farmácia OR Estudantes de Medicina OR Aluno OR
Alunos OR Estudante OR Enfermeiras Estudantes OR Alunos de Enfermagem OR Estudante de Enfermagem OR Enfermeiros Estudantes
Staphylococcus aureus
Resistência à meticilina
PubMed/ WEB OF SCIENCE/ SCOPUS
"Students" OR "Students, Health Occupations" OR "Students, Nursing" OR "Students, Pharmacy" OR "Students, Medical" OR Students, Dental" OR "Health
Occupations Students" OR "Health Occupations Student" OR "Student, Nursing" OR "Nursing Student" OR "Nursing Students" OR "Pharmacy Students"
OR "Student, Pharmacy" OR "Pharmacy Student" OR "Medical Students" OR "Student, Medical" OR "Medical Student" OR "Dental Students" OR "Student,
Dental" OR "Dental Student"
"Staphylococcus aureus"
"Methicillin Resistance" OR "Resistance, Methicillin" OR "Methicillin-Resistant" OR "Methicillin Resistant"
CINAHL
Students, Health Occupations
Staphylococcus aureus
Methicillin-Resistant Staphylococcus Aureus




\section{Data processing and analysis}

The studies thus found were exported to the Endnote reference manager software, version 20 (Clarivate Analytics, Philadelphia, United States), in order to identify duplicates and gather together all publications. In addition, the reference lists of these articles were consulted in order to find any additional studies. The selection of studies followed the recommendations of the Preferred Reporting Items for Systematic Reviews and Meta-Analyses (PRISMA) ${ }^{9}$ (Figure 1).

For data analysis and extraction, a data collection instrument that had been validated by Ursi was chosen for this study and was adapted for use in it. ${ }^{10}$ Furthermore, the protocol for this review was previously assessed by experts in the method used. After fully evaluating the texts, a descriptive analysis on the results found was carried out, in which a synthesis of all the studies included in the review was presented, along with comparisons between them.

\section{RESULTS}

The final sample for this review comprised 30 primary articles, which were characterized taking into account the authors, year of publication, country, objective and main results (Table 2). These studies were published in the years 2010,2012, 2013, 2014, 2015, 2016, 2017, 2018 and 2019.,3,7,11-37

Regarding the locations of the studies, they were carried out in Brazil, Malaysia, Colombia, China, Palestine, Spain, Brunei, India, Turkey, Czech Republic, Saudi Arabia, Madagascar, Pakistan, Nepal, Tanzania, South Korea, Iran, Ireland, Jordan, Italy, Nigeria, Poland and Ethiopia. ${ }^{3,5,7,11,12,14-22,24-37}$

The populations addressed by the researchers of these 30 studies were nursing students, medical students, health science students and dental students. ${ }^{3,5,7,12-18,20,21,23-25,27,29-30,33-37}$ Two studies involved students from more than one undergraduate course. ${ }^{11,22,28}$

To detect colonizing microorganisms, samples were collected using the technique of swab smears from nasal specimens, in all of these studies except for four studies, in which specimens were collected from more than one anatomical site. . $^{3,5,7,15-17,18-27-30,33-37}$

Regarding the prevalence of MRSA, the student population in some studies was divided into groups before exposure to healthcare and after such exposure. ${ }^{14,19,21,23,26}$ The percentages found are shown in Table 3.

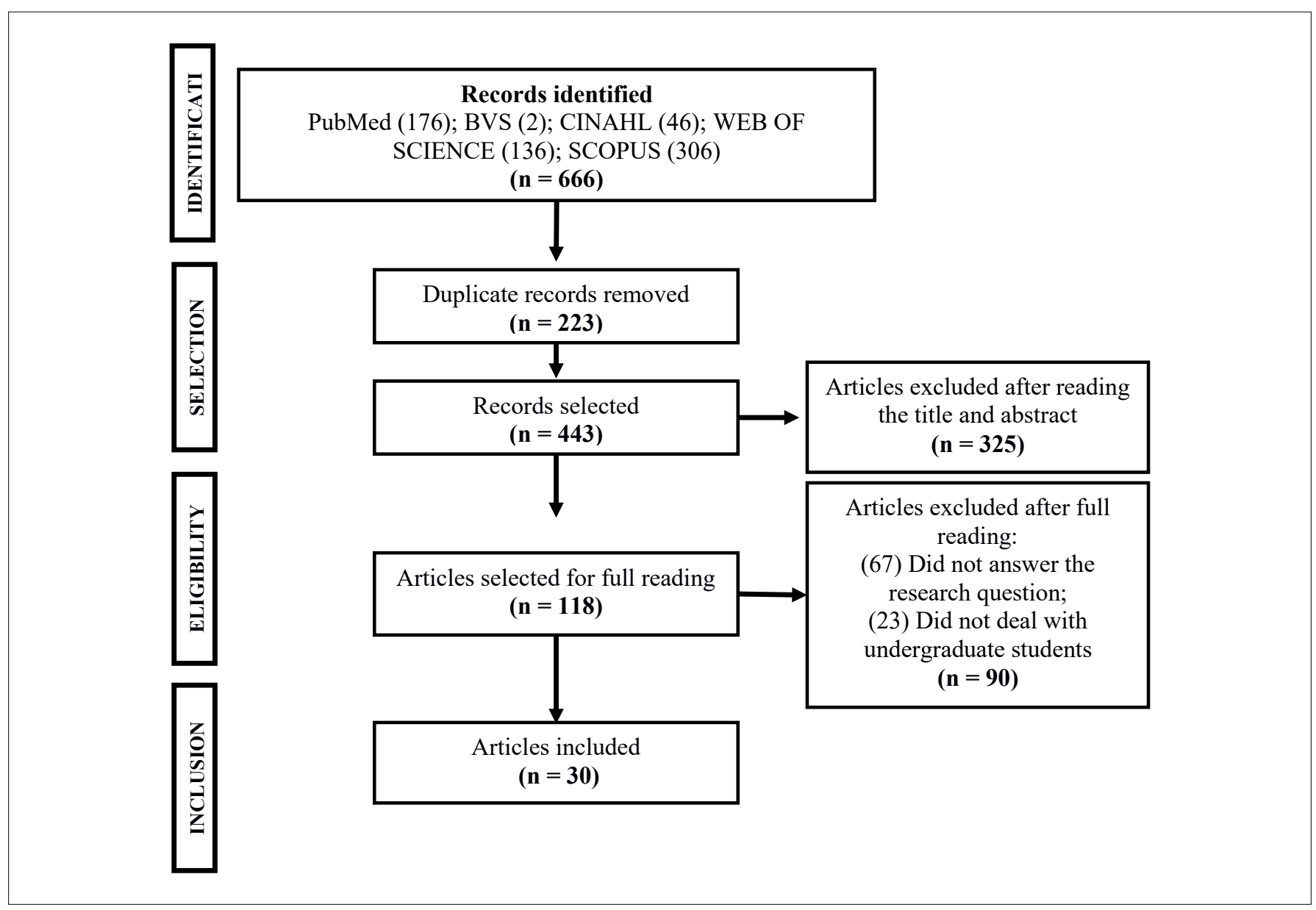

Figure 1. Study selection flowchart. Teresina (PI), Brazil, 2020. 
Table 2. Characterization of studies included in this review $(n=30)$. Teresina (PI), Brazil, 2020

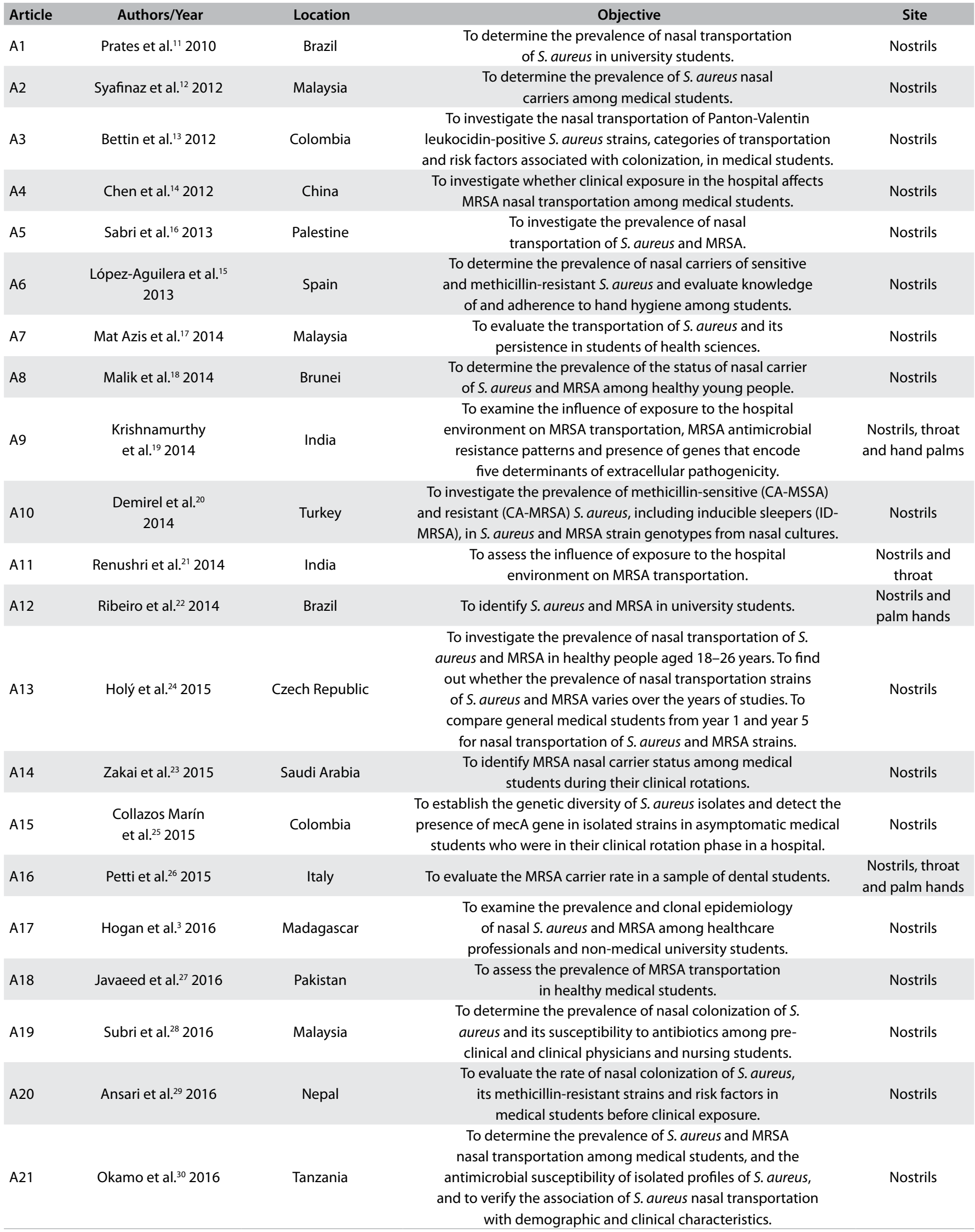


Table 2. Continuation

\begin{tabular}{|c|c|c|c|c|}
\hline Article & Authors/Year & Location & Objective & Site \\
\hline A22 & Baek et al. ${ }^{31} 2016$ & South Korea & $\begin{array}{l}\text { To determine the prevalence rate of nasal colonization } \\
\text { by MRSA among dental students and identify } \\
\text { the characteristics of the strains isolated. }\end{array}$ & Nostrils \\
\hline A24 & $\begin{array}{l}\text { Abroo et al. } \\
2017\end{array}$ & Iran & $\begin{array}{l}\text { To investigate the prevalence, antimicrobial susceptibility and } \\
\text { molecular factors characteristic of CA (community acquired) MRSA } \\
\text { among two groups of college students (medical and non-medical). }\end{array}$ & Nostrils \\
\hline A25 & Budri et al. ${ }^{33} 2018$ & Ireland & $\begin{array}{l}\text { To investigate co-located nasal Staphylococcus aureus and } \\
\text { coagulase-negative staphylococci (CoNS), recovered from healthy } \\
\text { medical students in a preclinical year and the transportation } \\
\text { of genes and common elements to both species that may } \\
\text { contribute to the evolution of S. aureus and MRSA. }\end{array}$ & Nostrils \\
\hline A26 & Al-Tamimi et al. ${ }^{34} 2018$ & Jordan & $\begin{array}{l}\text { To investigate the prevalence, standard antimicrobial } \\
\text { susceptibility, antibiotic resistance genes and risk } \\
\text { factors of medical students with MRSA. }\end{array}$ & Nostrils \\
\hline A28 & Onanuga et al. ${ }^{36} 2019$ & Nigeria & $\begin{array}{l}\text { To determine the antibiogram and the virulent characteristics } \\
\text { of nasal S. aureus, accessing its profile of resistance to } \\
\text { antibiotics and potential pathogens in healthy students at } \\
\text { the University of the Niger Delta, Bayelsa State, Nigeria. }\end{array}$ & Nostrils \\
\hline A29 & $\begin{array}{c}\text { Szymanek-Majchrzak } \\
\text { et al. }{ }^{37} 2019\end{array}$ & Poland & $\begin{array}{l}\text { To evaluate and compare the level of colonization of } \\
\text { S. aureus (MRSA or MSSA) among medical students } \\
\text { and evaluate the sensitivity of the strains. }\end{array}$ & Nostrils \\
\hline
\end{tabular}

\section{DISCUSSION}

Worldwide, occurrence of healthcare-associated infections (HAI) is one of the main public health problems, with severe human and economic repercussions. According to the Centers for Disease Control and Prevention (CDC), MRSA infections have outperformed HIV as the leading cause of morbidity and mortality in the United States. ${ }^{38}$

Studies have revealed high prevalence of MRSA in patients and healthcare professionals with exposure to the healthcare system. ${ }^{23,38,39}$ However, the results systematized in the present study revealed that presence of MRSA has also been reported among non-hospitalized healthy individuals, such as undergraduate students, ranging from $0.0 \%$ to $15.3 \% .^{14,25,26}$

Data in the literature have highlighted occurrences of MRSA infection in healthy populations that live in agglomerations or experience such conditions but which have little or no contact with healthcare services, as is the case of undergraduate students within the field of healthcare. ${ }^{1,40}$ This was observed in the present study, thus indicating that MRSA infection was present in students who were not exposed to hospital environments. This may indicate the presence of community-acquired MRSA strains. ${ }^{1}$ It needs to be borne in mind that in the studies discussed here, students who had been hospitalized within the last few months had been excluded, considering that hospitalization could be a confounding factor for occurrences of MRSA.

Identification of high frequencies of MRSA in students before they were exposed to experiences of clinical care is a matter for concern. It indicates that there is a need for effective infection prevention and control policies, in relation to hygiene and surveillance. ${ }^{5}$

Clinical practice among students in the field of healthcare is part of the teaching-learning process. In relation to this process, there is exposure to occupational risks, especially through recognition of the variability of care provided to patients. ${ }^{1,5}$ In this regard, studies that have addressed the prevalence of MRSA among students after exposure to hospital environments can provide evidence that exposure to MRSA in hospitals can play a critical role in achieving nasal colonization by MRSA.

According to the literature, the nostrils are the main colonization site for Staphylococcus aureus, whose prevalence reaches, on average, $40 \%$ in the adult population. ${ }^{1,5-6}$ Possibly for this reason, the nasal 
Table 3. Prevalence of methicillin-resistant Staphylococcus aureus, according to the studies included in this review

\begin{tabular}{|c|c|c|c|}
\hline & $\begin{array}{l}\text { General } \\
\text { students }\end{array}$ & $\begin{array}{l}\text { Students before } \\
\text { clinical exposure }\end{array}$ & $\begin{array}{l}\text { Students after } \\
\text { clinical exposure }\end{array}$ \\
\hline A1 & $2.4 \%$ & - & - \\
\hline $\mathrm{A} 2$ & $0.0 \%$ & - & - \\
\hline A3 & $1.61 \%$ & - & - \\
\hline A4 & $2.2 \%$ & $1.9 \%$ & $2.4 \%$ \\
\hline A5 & $9.0 \%$ & - & - \\
\hline A6 & $2.1 \%$ & - & - \\
\hline A7 & $3.3 \%$ & - & - \\
\hline A8 & - & $0.0 \%$ & - \\
\hline A9 & $6.8 \%$ & $4.0 \%$ & $9.0 \%$ \\
\hline A10 & $3.0 \%$ & - & - \\
\hline A11 & $8.2 \%$ & $4.0 \%$ & $11.8 \%$ \\
\hline A 12 & $1.9 \%$ & - & - \\
\hline A13 & $0.0 \%$ & - & - \\
\hline A14 & $15.3 \%$ & $0.0 \%$ & $6.7 \%$ \\
\hline A15 & $14.3 \%$ & - & - \\
\hline A16 & $3.2 \%$ & $3.1 \%$ & $0.0 \%$ \\
\hline A17 & $1.3 \%$ & - & - \\
\hline A18 & $5.5 \%$ & - & - \\
\hline A19 & $0.0 \%$ & - & - \\
\hline A20 & - & $4.0 \%$ & - \\
\hline A21 & $0.3 \%$ & $0.0 \%$ & $0.3 \%$ \\
\hline$A 22$ & $3.1 \%$ & - & $3.1 \%$ \\
\hline A23 & $6.1 \%$ & - & - \\
\hline A24 & $13.1 \%$ & - & - \\
\hline A25 & $2.1 \%$ & $2.1 \%$ & - \\
\hline A26 & $4.1 \%$ & - & - \\
\hline A27 & $8 \%$ & - & - \\
\hline A28 & $7.1 \%$ & - & - \\
\hline A29 & $0.1 \%$ & - & - \\
\hline A30 & $8.4 \%$ & - & - \\
\hline
\end{tabular}

cavity was the site most chosen by researchers for sample collection in their studies, thus showing the importance of the upper airways in transmission and acquisition of pathogenic microorganisms. The throat and palms are also important reservoirs for MRSA. 19,21,22,26

It is known that students in the field of healthcare, as they progress through the curriculum with increasing complexity of care practices, whether in hospitals or other healthcare delivery environments, become carriers of microbes. In this, acquisition of Staphylococcus aureus is considered to be a major concern, especially with regard to MRSA. ${ }^{1}$

Thus, MRSA rates in students may increase according to their clinical exposure, as well as from isolated occurrences. In another study, there was greater potential for virulence in samples from groups working in clinics. ${ }^{5}$ This aspect of infection could not be analyzed in the present study, since the studies included in this review were cross-sectional, which did not allow the study sample to be monitored.

The prevalences found need to be analyzed with caution, considering that occurrences of infections caused by MRSA may differ according to the scenarios within which they occur. This may be due to measures that are taken to control infection and may be dependent on effective implementation. ${ }^{5}$ Likewise, the MRSA rate also varies in different locations..$^{27,41}$

This study presented some limitations due to the choice of databases and keywords. Use of the CINAHL database may have restricted the search, as it is a specific database for the field of nursing. In addition, the choice of databases and keywords may have camouflaged studies on the same topic that were not indexed in the same database. Hence, it can be suggested that similar investigations should be conducted, with cross-referencing of other databases, in order to investigate Brazilian scientific production on colonization by Staphylococcus aureus among healthcare students.

\section{CONCLUSION}

The prevalence of colonization by methicillin-resistant Staphylococcus aureus among healthcare students is high, and the nasal cavity was cited in this study as an important reservoir for these microorganisms.

Efforts need to be made to implement standards and routines that are designed to limit the spread of MRSA strains among students, given that once MRSA has become established within a community, its eradication and control is difficult. Furthermore, in view of the high morbidity and mortality and exponential growth of series of microbial resistance, implementation of control strategies is prudent.

Therefore, education on infection control measures in undergraduate healthcare courses is of great importance, as also is implementation of adequate and effective infection control programs to reduce the prevalence of MRSA.

\section{REFERENCES}

1. Carvalho MS, Andrade DF, Sousa ÁF, et al. Nasal colonization with Staphylococcus aureus in nursing students: ground for monitoring. Rev Bras Enferm. 2016;69(6):1046-51. PMID: 27925079; https://doi. org/10.1590/0034-7167-2016-0210.

2. Abulkasim GS, Shukla HK, Masih H. Antimicrobial resistance of staphylococcus aureus among healthy and adult students. Int J Pharm Sci Res. 2017;8(12):5247-51. Available from: https://ijpsr.com/bft-article/ antimicrobial-resistance-of-staphylococcus-aureus-among-healthyand-adult-students/?view=fulltext. Accessed in 2021 (May 10).

3. Hogan B, Rakotozandrindrainy $\mathrm{R}, \mathrm{Al}-\mathrm{Emran} \mathrm{H}$, et al. Prevalence of nasal colonisation by methicillin-sensitive and methicillin-resistant Staphylococcus aureus among healthcare workers and students in Madagascar. BMC Infect Dis. 2016;16(1):420. PMID: 27526771; https:// doi.org/10.1186/s12879-016-1733-6.

4. Almeida GCM, Lima NG, Santos MM, Melo MCN, Lima KC. Colonização nasal por Staphylococcus sp. em pacientes internados. Acta Paul Enferm. 2014;27(3):273-9. https://doi.org/10.1590/1982-0194201400046. 
5. Efa F, Alemu Y, Beyene G, Gudina EK, Kebede W. Methicillin-resistant Staphylococcus aureus carriage among medical students of Jimma University, Southwest Ethiopia. Heliyon. 2019;5(1):e01191. PMID: 30775580; https://doi.org/10.1016/j.heliyon.2019.e01191.

6. Moremi N, Claus H, Vogel U, Mshana SE. The role of patients and healthcare workers Staphylococcus aureus nasal colonization in occurrence of surgical site infection among patients admitted in two centers in Tanzania. Antimicrob Resist Infect Control. 2019;8:102. PMID: 31236269; https://doi.org/10.1186/s13756-019-0554-y.

7. Abroo S, Hosseini Jazani N, Sharifi Y. Methicillin-resistant Staphylococcus aureus nasal carriage between healthy students of medical and nonmedical universities. Am J Infect Control. 2017;45(7):709-12. PMID: 28359610; https://doi.org/10.1016/j.ajic.2017.02.034.

8. Galvão CM, Mendes KDS, Silveira RCCP. Revisão integrativa: método de revisão para sintetizar as evidências disponíveis na literatura. In: Brevidelli MM, Sertório SCM, editors. Trabalho de conclusão de curso: guia prático para docentes e alunos da área da saúde. São Paulo: látria; 2010. p. 105-26.

9. Moher D, Liberati A, Tetzlaff J, Altman DG; PRISMA Group. Preferred reporting items for systematic reviews and meta-analyses: the PRISMA statement. PLoS Med. 2009;6(7):e1000097. PMID: 19621072; https:// doi.org/10.1371/journal.pmed.1000097.

10. Ursi ES, Gavão CM. Prevenção de lesões de pele no perioperatório: revisão integrativa da literatura [Perioperative prevention of skin injury: an integrative literature review]. Rev Lat Am Enfermagem. 2006;14(1):124-31. PMID: 16532249; https://doi.org/10.1590/s0104-11692006000100017.

11. Prates KA, Torres AM, Garcia LB, et al. Nasal carriage of methicillinresistant Staphylococcus aureus in university students. Braz J Infect Dis. 2010;14(3):316-8. PMID: 20835520.

12. Syafinaz AM, Nur Ain NZ, Nadzirahi SN, et al. Staphylococcus aureus Nasal Carriers Among Medical Students in A Medical School. Med J Malaysia. 2012;67(6):636-8. PMID: 23770966.

13. Bettin A, Causil C, Reyes N. Molecular identification and antimicrobial susceptibility of Staphylococcus aureus nasal isolates from medical students in Cartagena, Colombia. Braz J Infect Dis. 2012;16(4):329-34. PMID: 22846119; https://doi.org/10.1016/j.bjid.2012.06.017.

14. Chen CS, Chen CY, Huang YC. Nasal carriage rate and molecular epidemiology of methicillin-resistant Staphylococcus aureus among medical students at a Taiwanese university. Int J Infect Dis. 2012;16(11):e799803. PMID: 2287817; https://doi.org/10.1016/j.jiji.2012.07.004.

15. López-Aguilera S, Goñi-Yeste M del M, Barrado L, et al. Colonización nasal por Staphylococcus aureus en estudiantes de medicina: importancia en la transmisión hospitalaria [Staphylococcus aureus nasal colonization in medical students: importance in nosocomial transmission]. Enferm Infecc Microbiol Clin. 2013;31(8):500-5. PMID: 23352260; https://doi. org/10.1016/j.eimc.2012.12.005.

16. Sabri I, Adwan K, Essawi TA, Farraj MA. Molecular characterization of methicillin-resistant Staphylococcus aureus isolates in three different Arab world countries. Eur J Microbiol Immunol (Bp). 2013;3(3):183-7. PMID: 24265936; https://doi.org/10.1556/EuJMI.3.2013.3.5.
17. Mat Azis N, Hamid AAB, Pung HP, et al. Staphylococcus aureus infection risk in a population of health sciences students at a public university. Iranian J Publ Health 2014;43(Suppl 12):112-6. Available from: https://ijph.tums. ac.ir/index.php/ijph/article/view/4887. Accessed in 2021 (May 10).

18. Malik NFA, Muharram SH, Abiola O. Staphylococcus aureus nasal carriage in young healthy adults in Brunei Darussalam. Brunei Int Med J. 2014;10(2):78-84

19. Krishnamurthy V, Saha A, Renushri BV, Nagaraj ER. Methicillin Resistant Staphylococcus aureus Carriage, Antibiotic Resistance and Molecular Pathogenicity among Healthy Individuals Exposed and Not Exposed to Hospital Environment. J Clin Diagn Res. 2014;8(7):DC04-8. PMID: 25177563; https://doi.org/10.7860/JCDR/2014/8409.4638.

20. Demirel G, Findik D, Dagi HT, Arslan U. Community-acquired methicillin-resistant Staphylococcus aureus and genotypes among university students in Turkey. Southeast Asian J Trop Med Public Health. 2014;45(6):1401-9. PMID: 26466426.

21. Renushri BV, Saha A, Nagaraj ER, et al. Screening for methicillin-resistant Staphylococcus aureus carriers among individuals exposed and not exposed to the hospital environment and their antimicrobial sensitivity pattern. Annals of Tropical Medicine and Public Health. 2014;7(1):19-24. Available from: https://cyberleninka.org/article/n/503731. Accessed in 2021 (May 10).

22. Ribeiro IF, Silva SFR, Silva SL, et al. Identificação de Staphylococcus aureus e Staphylococcus aureus resistente à meticilina em estudantes universitários. Rev Ciênc Farm Básica Apl. 2014;35(2):299-302. Available from: https://rcfba.fcfar.unesp.br/index.php/ojs/article/view/145/143. Accessed in 2021 (May 10).

23. Zakai SA. Prevalence of methicillin-resistant Staphylococcus aureus nasal colonization among medical students in Jeddah, Saudi Arabia. Saudi Med J. 2015;36(7):807-12.PMID:26108584; https:/doi.org/10.15537/smj.2015.7.11609.

24. Holý O, Vlčková J, Matoušková I, Kolář M. Prevalence výskytu nosního nosičství kmenů Staphylococcus aureus a meticilin rezistentních kmenů S. aureus (MRSA) u studentů všeobecného lékařství LF UP v Olomouci [The prevalence of nasal carriage of Staphylococcus aureus and methicillin-resistant $\mathrm{S}$. aureus (MRSA) among general medicine students of the Palacky University Olomouc]. Epidemiol Mikrobiol Imunol. 2015;64(2):98-101. PMID: 26099614.

25. Collazos Marín LF, Estupiñan Arciniegas G, ChavezVivas M. Characterization of Staphylococcus aureus Isolates That Colonize Medical Students in a Hospital of the City of Cali, Colombia. Int J Microbiol. 2015;2015:358489. PMID: 26495001; https://doi.org/10.1155/2015/358489.

26. Petti $S$, Kakisina N, Volgenant CM, et al. Low methicillin-resistant Staphylococcus aureus carriage rate among Italian dental students. Am J Infect Control. 2015;43(12):e89-91. PMID: 26384585; https://doi. org/10.1016/j.ajic.2015.08.008.

27. Javaeed A, Khan S, Haqsubhani RU, Ghauri SK, Jahan S. Methicillin Resistant Staphylococcus Aureus Prevalence of Nasal Carriage among Healthy MBBS Students of Continental Medical College, Lahore. P J M HS. 2016;10(3): 1057-9. Available from: https://pjmhsonline.com/2016/ july_sep/pdf/1057.pdf. Accessed in 2021 (May 10). 
28. Subri NIBM, Hlaing SS, Myint, T, et al. Nasal Carriage of Staphylococcus aureus and Its Antibiotic Susceptibility Pattern among Medical and Nursing Students. Asian J Pharm. 2016;10(4):736-40. https://dx.doi. org/10.22377/ajp.v10i04.917.

29. Ansari S, Gautam R, Shrestha S, et al. Risk factors assessment for nasal colonization of Staphylococcus aureus and its methicillin resistant strains among pre-clinical medical students of Nepal. BMC Res Notes. 2016;9:214. PMID: 27068121; https://doi.org/10.1186/s13104-016-2021-7.

30. Okamo B, Moremi N, Seni J, et al. Prevalence and antimicrobial susceptibility profiles of Staphylococcus aureus nasal carriage among pre-clinical and clinical medical students in a Tanzanian University. BMC Res Notes. 2016;9:47. PMID: 26817605; https://doi.org/10.1186/s13104-016-1858-0.

31. Baek YS, Baek SH, Yoo YJ. Higher nasal carriage rate of methicillinresistant Staphylococcus aureus among dental students who have clinical experience. J Am Dent Assoc. 2016 May;147(5):348-53. PMID: 26778005; https://doi.org/10.1016/j.adaj.2015.12.004

32. Radhakrishna M,Taneja A, Rao P. Nasal carriage of Staphylococcus aureus with special emphasis on methicillin-resistant Staphylococcus aureus among students of a south Indian medical college - prevalence and antibiogram pattern. Asian J Pharm Clin Res. 2016;9(8):129-32. https:// doi.org/10.22159/ajpcr.2016.v9s2.13274.

33. Budri PE, Shore AC, Coleman DC, et al. Observational cross-sectional study of nasal staphylococcal species of medical students of diverse geographical origin, prior to healthcare exposure: prevalence of SCCmec, fusC, fusB and the arginine catabolite mobile element (ACME) in the absence of selective antibiotic pressure. BMJ Open. 2018 Apr 20;8(4):e020391. PMID: 29678979; http://dx.doi.org/10.1136/bmjopen-2017-020391.

34. Al-Tamimi M, Himsawi N, Abu-Raideh J, Jazar DA, Al-jawaldeh $H$, Mahmoud SAH. Nasal colonization by methicillin-sensitive and methicillin-resistant Staphylococcus aureus among medical students. J Infect Dev Ctries 2018; 12(5):326-35. https://doi.org/10.3855/jidc.9908

35. Suhaili Z, Rafee $P^{\prime}$, Mat Azis $N$, et al. Characterization of resistance to selected antibiotics and Panton-Valentine leukocidin-positive Staphylococcus aureus in a healthy student population at a Malaysian University. Germs. 2018;8(1):21-30.PMID:29564245; https://doi.org/10.18683/germs.2018.1129.

36. Onanuga A, Eboh DD, Okou GT. Antibiogram and Virulence Characteristics of Multi-drug Resistant Staphylococcus aureus from Nasal Cavity of Healthy Students of Niger Delta University, Amassoma, Bayelsa State, Nigeria. Journal of Clinical and Diagnostic Research. 2019;13(7):24-9. https://doi.org/10.7860/JCDR/2019/41396.13031.

37. Szymanek-Majchrzak K, Kosiński J, Żak K, et al. Prevalence of methicillin resistant and mupirocin-resistant Staphylococcus aureus strains among medical students of Medical University in Warsaw. Przegl Epidemiol. 2019;73(1):39-48. PMID: 31134773; https://doi.org/10.32394/pe.73.05.

38. Centers for disease control and prevention (CDC). Healthcare-associated infections. Current HAI Progress Report. 2019 National and State Healthcare-
Associated Infections Progress Report. Available from: http://www.cdc. gov/hai/progress-report/index.html. Accessed in 2021 (May 10).

39. Rohde RE, Rowder C, Patterson T, et al. Methicillin resistant Staphylococcus aureus (MRSA): an interim report of carriage and conversion rates in nursing students. Clin Lab Sci. 2012;25(2):94-101. PMID: 22693778; https://doi.org/10.29074/ascls.25.2.94

40. Evangelista SS, Oliveira AC. Staphylococcus aureus meticilino resistente adquirido na comunidade: um problema mundial. Rev Bras Enferm. 2015;68(1):136-41. https://doi.org/10.1590/0034-7167.2015680119p.

41. Conceição T, de Lencastre H, Aires-de-Sousa M. Carriage of Staphylococcus aureus among Portuguese nursing students: A longitudinal cohort study over four years of education. PLoS One. 2017;12(11):e0188855. PMID: 29190721; https://doi.org/10.1371/journal.pone.0188855.

Authors' contributions: Oliveira EMN: conducted the data survey and critical analysis; wrote the manuscript and agreed with its final version; Carvalho ARB: conducted the data survey and critical analysis; wrote the manuscript and agreed with its final version; Ferreira AM: conducted the data survey, drafted the manuscript and agreed with its final version; Moura LKB: conducted the data survey, drafted the manuscript and agreed with its final version; Valle ARMC: made a critical analysis on the manuscript, reviewed it and agreed with its final version; Freitas DRJ: made a critical analysis on the manuscript, reviewed it and agreed with its final version; and Moura MEB: made a critical analysis on the manuscript, reviewed it and agreed with its final version. All authors hold themselves fully responsible for the study, regarding the accuracy or integrity of the data and the data interpretation in the text

Sources of funding: Coordenação de Aperfeiçoamento de Pessoal de Nível Superior (CAPES), grant number 88882.446296/2019-01

Conflict of interest: The authors declare that there were no conflicts of interest, either in carrying out the research project actions or in writing this manuscript

Date of first submission: September 22, 2020

Last received: April 6, 2021

Accepted: April 22, 2021

\section{Address for correspondence:}

Erika Morganna Neves de Oliveira

Universidade Federal do Piauí (UFPI), Campus Universitário Ministro Petrônio Portella

Ininga - Teresina (PI) - Brasil

CEP 64049-550

Tel. (+55 86) 3215-5513

E-mail:morgannaneves@hotmail.com 